\title{
Radiologic Management of Haemoptysis: Diagnostic and Interventional Bronchial Arterial Embolisation
}

\section{Radiologisches Management von Hämoptysen: Diagnostik und Interventionelle Bronchialarterienembolisation}

Authors

Affiliations
H. Ittrich' ${ }^{1}$ H. Klose ${ }^{2}$, G. Adam ${ }^{1}$

Diagnostic and Interventional Radiology Department and Clinic, Center for Radiology and Endoscopy, University Medical Center Hamburg-Eppendorf, Hamburg, Germany

2 Department of Internal Medicine II and Clinic - Section Pneumology, Center for Oncology, University Medical Center Hamburg-Eppendorf, Hamburg, Germany

\author{
Key words \\ haemoptysis \\ bronchial artery embolization \\ - BAE \\ - DSA \\ - multidetector computed \\ tomography \\ - MDCT
}

\section{Zusammenfassung}

Hämoptysen stellen einen lebensbedrohlichen pulmonalen Notfall mit hoher Mortalität dar, sind meist Symptome einer schwerwiegenden pulmonalen Grunderkrankung und erfordern eine sofortige Diagnostik und Therapie. Diagnostisch liefern das konventionelle Thoraxröntgen, die kontrastmittelunterstütze MehrschichtComputertomografie (MSCT) mit CT-Angiografie (CTA) und die Bronchoskopie Informationen zur zugrundeliegenden pulmonalen Erkrankung, zur Seitenlokalisation, zur Gefäßanatomie der Bronchialarterien (BA) und extrabronchialer Äste sowie zur Planung des interventionell-endovaskulären Eingriffs. Therapeutisch hat sich die Bronchialarterienembolisation (BAE) bei Durchführung durch einen erfahrenen Interventionalisten mit Kenntnissen der BA-Anatomie und möglicher Fallstricke als sichere und effektive Technik bewährt und ist Erstlinientherapie bei massiven und rekurrierenden Hämoptysen sowie im Vorfeld einer elektiven Operation. Rezidivierende Hämoptysen sind nicht ungewöhnlich und erfordern nach Abklärung möglicher extrabronchialer, systemisch- und pulmonalarterieller Blutungsquellen eine erneute BAE. Diese Übersichtsarbeit soll einen Überblick zur Historie, zu anatomischen und pathophysiologischen Grundlagen und zum klinischen Hintergrund der Hämoptysen sowie zu Diagnostik, Management, Therapie und Ergebnissen der BAE geben.

Kernaussagen:

- Hämoptysen sind lebensbedrohlich und erfordern eine dringende Diagnostik und Therapie.

- Thorax-Röntgen, Bronchoskopie und eine Kontrastmittel-unterstützte MSCT mit CTA sollten vor therapeutischer Bronchialarterienembolisation (BAE) erfolgen.

- Die BAE zur Therapie von massiven und rezidivierenden Hämoptysen ist sicher und effektiv.

\section{Abstract \\ $\nabla$}

Hemoptysis can be a life-threatening pulmonary emergency with high mortality, is symptomatic of an underlying severe pulmonary disease and requires immediate diagnosis and treatment. Diagnostically, bronchoscopy, conventional chest $\mathrm{x}$ ray and contrast-enhanced multislice computed tomography (MSCT) with CT angiography (CTA) provide information regarding the underlying pulmonary disease, bleeding site, the vascular anatomy of the bronchial arteries (BA) and extrabronchial branches, as well a basis for planning of endovascular intervention. Therapeutically, bronchial artery embolization (BAE) is a safe and effective technique in the hands of an experienced interventionist with profound knowledge of the BA anatomy and possible pitfalls as well as experience with first-line therapy of recurrent and massive hemoptysis or as an intervention prior to elective surgery. Recurrent episodes of hemoptysis are not uncommon and require a prompt repeat BAE after exclusion of extrabronchial systemic and pulmonary artery bleeding sources. This review article should give an overview of the history, anatomical and pathophysiological basics and the clinical context of hemoptysis and diagnosis, as well as a survey of management, treatment and results of BAE.

Key Points:

- Hemoptyses are life threatening and require urgent diagnostic and therapy.

- Chest X-ray, bronchoscopy, and contrast-enhanced MSCT with CTA should be carried out before therapeutic bronchial artery embolization (BAE).

- BAE for the treatment of massive and recurrent hemoptysis is safe and effective.

- False embolization in spinal branches of BA are the most serious complication of a BAE.

- Repeatedly BAE refractory cases should undergo elective surgery. 
- Fehlembolisationen in spinal versorgende Äste von BA sind die schwerste Komplikation einer BAE.

- Wiederholt BAE-refraktäre Fälle wie Aspergillome sollten operativ saniert werden.

\section{Citation Format:}

- Ittrich H, Klose H, Adam G Radiologisches Management von Hämoptysen: Diagnostik und Interventionelle Bronchialarterienembolisation. Fortschr Röntgenstr 2015; 187: 248-259

\section{Introduction}

\section{$\nabla$}

Hemoptysis represents a life-threatening emergency situation requiring immediate diagnosis and therapy. This situation occurs frequently in clinical practice and requires a prompt investigation of the underlying cause as well as a rapid therapeutic response. Despite substantial advances in intensive care in recent decades, massive hemoptysis remains a clinical challenge both to diagnosis and therapy $[1,2]$. Purely conservative treatment of massive hemoptysis results in a $50-100 \%$ mortality [3], while asphyxia from intrabronchial blood accumulation rather than blood loss is the cause of death [4] in most of these cases. Up until the $1990 \mathrm{~s}$, the therapy of choice for hemoptysis was surgery. The mortality in cases of intermittent hemoptysis was between 7 and $18 \%$; mortality rates for emergency surgeries were between 37 and $42 \%$ [5 - 7].

A minimally-invasive procedure using bronchial artery embolization (BAE) was first introduced at the start of the $1970 \mathrm{~s}$ [8], and in the past 3 decades has been recognized as the most effective and safe non-surgical procedure for primary therapy of massive or recurring hemoptysis as well as for patient stabilization prior to elective surgery [ $9-15]$. Surgery has maintained its therapeutic value in the case of special indications, such as traumatic injury to pulmonary vessels, bronchial adenoma, or therapy-resistant aspergilloma [16].

This article will provide an overview of the history, clinical background, anatomy and pathophysiology, diagnosis of massive hemoptysis and related therapy using BAE.

\section{History}

$\nabla$

The existence of the bronchial arteries (BA), the internal vessels of the lung has been known since before the time of Galen (129-199 A. D.); these have been illustrated by artists such as Leonardo da Vinci [17]. In the 1960 s, non-selective angiography of the thoracic aorta was first used to image pulmonary and pulmonary vascular anatomy $[18,19]$. In 1963 Viramonte first described the angiography of the bronchial arteries [20]. This technique was first used to differentiate benign and malignant pulmonary space consumption and to determine the extent of bronchiectases [20 - 22]. In many cases this procedure resulted in transverse myelitis [23, 24]. The first successful selective BAE to treat hemoptysis was performed in France by Remy et al. in 1974 [25]. Since then, numerous authors have presented various techniques and related results.

\section{Anatomical and pathophysiological principles \\ $\nabla$}

The lungs possess a dual blood supply via the pulmonary arteries, which in pulmonary circulation provide gas exchange with the alveoli and make up about $99 \%$ of arterial supply, and the bronchial arteries, which as internal vessels provide the remaining $1 \%$ of the supply [26]. That latter extend along the bronchi and subdivide into supplying branches to the trachea, the bronchi, the vasa vasorum of the pulmonary arteries and veins as well as to the aorta, to the small bronchopulmonary branches of the lung, diaphragmatic and mediastinal visceral pleura as well as to the central esophagus and subcarinal lymph nodes [17, 27, 28]. In a healthy subject, the bronchial arteries at the ostium measure less than $1.5 \mathrm{~mm}$, and less than $0.5 \mathrm{~mm}$ at the entrance to the bronchopulmonary segment [28]. Bronchial artery diameter greater than $2 \mathrm{~mm}$ in CT is generally classified as abnormal [29]. Between the pulmonary and bronchial arteries there are numerous bronchopulmonary anastomoses on the bronchial and lobular level which maintain a physiological right-left shunt of approx. $5 \%$ of the cardiac output and have a size of up to $325 \mu \mathrm{m}$ $[27,28]$. Venous drainage occurs by means of the bronchopulmonary shunts via the pulmonary veins as well as regularly via the bronchial veins into the azygos vein, hemiazygos vein and superior vena cava [17]. Furthermore, shunts to the coronary arteries have been described which have been incidentally detected during a coronary MDCT or angiography as congenital or postoperatively acquired fistulas from the coronary arteries to the bronchial arteries; these occur with a frequency of $0.61 \%$ [3037 , and can be the cause of anginal symptoms due to a steal effect [38]. Similarly, bronchial artery fistulas with reversed flow to the coronary arteries have been described; these can potentially lead to severe cardiac complications in the course of bronchial artery embolization [39-42].

The origin of and supply to the lungs via the bronchial arteries are variable ( Fig. 1). About $70 \%$ of the bronchial arteries emanate from the descending thoracic aorta between the end plate of the 5 th thoracic vertebra and the base of the 6th thoracic vertebra $[17,26]$, frequently at the height where the aorta crosses the left main bronchus. The remaining $30 \%$ of bronchial arteries originate from other vascular territories such as the subclavian artery, internal thoracic artery, pericardiacophrenic artery, inferior phrenic artery, thyrocervical trunk, brachiocephalic artery, the vertebral artery, the front of the aortic arch, the abdominal aorta or, in rare cases, the left gastric artery $[17,43,44]$. In the majority of cases, the right bronchial artery, together with the right-side intercostal artery forms a common intercostal bronchial trunk (ICBT) which is less frequently to be found on the left side. It should be noted that the ICBT can have a variable shape, and in $5-10 \%$ of known cases can branch into the anterior spinal artery (ASA) of the spinal cord $[4,45]$. The typical supply to the anterior potion of the spinal cord is via the ASA, which is fed by branches from the intercostal and lumbar arteries. In this case, the anterior spinal arteries follow a typical "hairpin" course with an ascending portion that enters a descending intraspinal segment via a sharp bend (passing through the neural foramen) before draining into the ASA. The largest spinal artery is the arteria radicularis magna, also known as the Adamkiewicz artery, which originates between the T8 and L4 vertebral segments, but can also in rare instances originate from a point as high as the 5 th thoracic vertebra [17]. Knowledge of anatomical supply relationships of the bronchial and anterior spinal arteries as well as their variants should be considered fundamental for successful endovascular BAE therapy as well as to prevent fatal misembolization (e.g. ASA with spinal ischemia). 


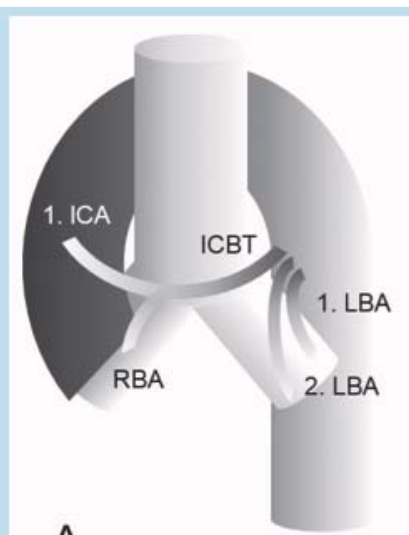

A

Fig. 1 Variants in the bronchial artery anatomy ([26, 36]): A Typ I with 2 BA left (LBA) and 1 BA right (RBA) from ICBT in 40,6\%, B Typ II with 1 LBA (from Aorta) and 1 RBA (from ICBT) in 21,3\%, C Typ III with 2 LBA (from Aorta) and 2 RBA (from ICBT + Aorta) $20,6 \%$ and D Typ IV with 1 LBA (from Aorta) and 2 RBA (from ICBT + Aorta) 9,7\%.
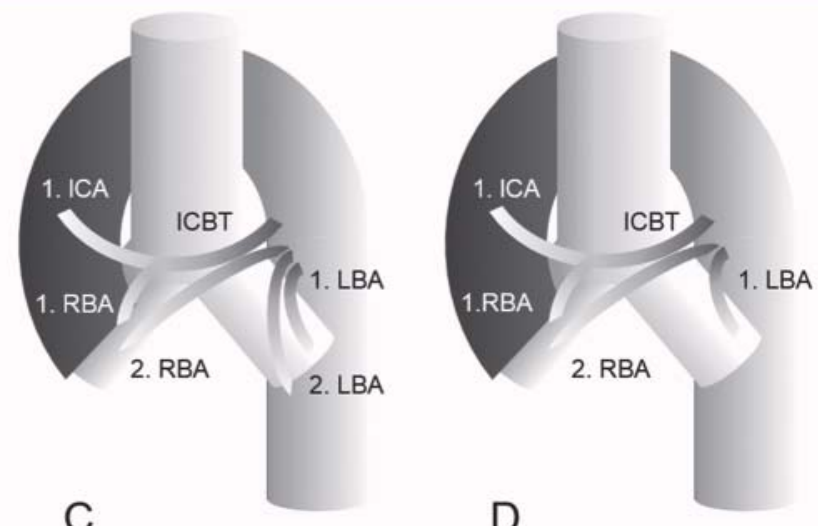

Abb. 1 Varianten in der Bronchialarterienanatomie (modifiziert nach [26, 36]). A Typ I mit 2 linken BA (LBA) und 1 rechten BA (RBA) aus dem ICBT in 40,6\%, B Typ II mit 1 LBA (aus Aorta) und 1 RBA (aus ICBT) in 21,3\%, C Typ III mit 2 LBA (aus Aorta) und 2 RBA (aus ICBT + Aorta) 20,6\% und D Typ IV mit 1 LBA (aus Aorta) und 2 RBA (aus ICBT + Aorta) 9,7\%.
Proliferation and enlargement of the bronchial arteries are the compensatory consequence of the expression of neoangiogenetic growth factors in cases of restriction of pulmonary circulation caused by hypoxic vasoconstriction, pulmonary thromboembolism or thrombosis, vasculitis or chronic inflammatory lung diseases [4, 28, $46-48]$. Since their walls are thinner and more fragile, these blood vessels are subject to systemic arterial pressure and are located in a region susceptible to chronic inflammation. They rupture more frequently with bleeding into the airways which is clinically exhibited as massive hemoptysis [28, 49].

\section{Clinical background}

Angiographic and bronchoscopic studies as well arterial oxygenation of expectorated blood have demonstrated that the bronchial arteries are the primary origin of hemoptysis [10] There are multiple causes of hemoptysis ( $\bullet$ Table 1 ). Most commonly hemoptysis occurs in the setting of chronic inflammatory pulmonary diseases, predominantly in cases of tuberculosis and as the result of aspergillus-populated cavities [11], but also may be caused by bronchiectasis resulting from chronic obstructive pulmonary disease (COPD) or cystic fibrosis (CF, lifetime risk 4\%) [50]), pneumoconiosis, bronchogenic or iatrogenic tumors (e.g. after endobronchial coil implantation (EBRC), ○ Fig. 2).

In rare instances, hemoptysis is caused by bleeding from the pulmonary arteries caused by a rupture of a congenital, infectious or vascular pathological pulmonary artery aneurysm or a pulmonary arteriovenous fistula (PAVM) [47, 51]. Hemoptysis resulting from a rupture of bronchial arterial (pseudo-) aneurysms is likewise a rarity [52 - 57].

Although most episodes of hemoptysis with low expectoration volumes can be treated with simple bed rest and supportive therapy, uncontrollable hemoptysis has a high mortality rate due to asphyxia and exsanguination. In the literature, massive hemoptysis has been defined to be between $100-1000 \mathrm{ml} / 24$ hours [4, 5, 47, 58]; however, between 300 and $600 \mathrm{ml}$ of bloody expectoration in 24 hours is generally considered to be massive [47]. With a tracheobronchial tree volume of $150-200 \mathrm{ml}, 300-400 \mathrm{ml}$ of blood in the alveolar space can lead to significant gas exchange

\begin{tabular}{|c|c|}
\hline \multirow[t]{12}{*}{ pulmonary disease } & malignant tumor \\
\hline & bronchitis \\
\hline & bronchiectasis \\
\hline & sarcoidosis \\
\hline & $\begin{array}{l}\text { chronic obstructive pulmonary disease } \\
\text { (COPD) }\end{array}$ \\
\hline & pneumonia \\
\hline & tuberculosis \\
\hline & aspergilloma \\
\hline & pulmonary abscess \\
\hline & cystic fibrosis \\
\hline & pneumoconiosis \\
\hline & lupus pneumonia \\
\hline \multirow[t]{7}{*}{ cardiovascular disease } & $\begin{array}{l}\text { pulmonary arteriovenous malformation } \\
\text { (PAVM) }\end{array}$ \\
\hline & pulmonary embolism \\
\hline & pulmonary hypertension \\
\hline & aortic/bronchial arterial aneurysm \\
\hline & $\begin{array}{l}\text { pulmonary arterial aneurysm (Rasmussen } \\
\text { aneurysm) }\end{array}$ \\
\hline & $\begin{array}{l}\text { vasculitis (Wegener's granulomatosis, Beh- } \\
\text { çet's syndrome, Osler-Weber-Rendu disease, } \\
\text { Goodpasture syndrome) }\end{array}$ \\
\hline & aortobronchial fistula \\
\hline \multirow[t]{6}{*}{ other causes } & iatrogenic (after needling, pleural drainage) \\
\hline & $\begin{array}{l}\text { iatrogenic after endobronchial coil implanta- } \\
\text { tion (EBRC) }\end{array}$ \\
\hline & coagulopathy/coagulation disorder \\
\hline & trauma \\
\hline & foreign body \\
\hline & $\begin{array}{l}\text { congenital pulmonary or cardiovascular } \\
\text { abnormality }\end{array}$ \\
\hline
\end{tabular}

inhibition and death through asphyxia [16] long before blood loss results in volume deficiency shock [2].

In the era prior to endovascular intervention, bronchial artery embolization therapy consisted of surgical resection of the hemorrhaging pulmonary lobe if there were no contraindications for lobectomy such as lack of blood flow localization, inadequate vital capacity of the lung or inoperable bronchial carcinoma [9]. 

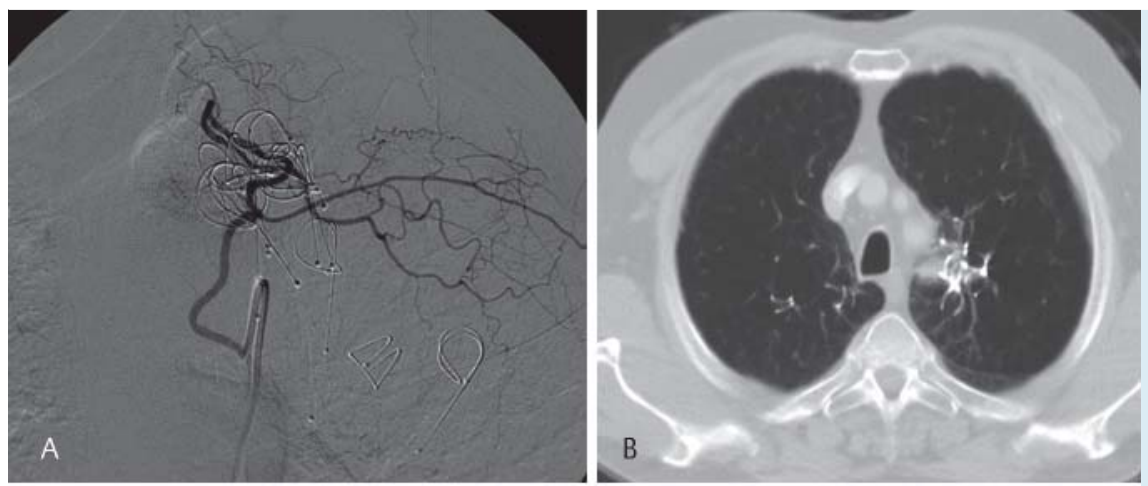

Fig. 2 Hemoptysis after therapy of an upper lung lobe pulmonary emphysema using endobronchial coils (EBRC) with areas of hypervascularization in the left paramediastinal upper lobe $\mathbf{A}$ DSA of left truncus intercostobronchialis, $\mathbf{B}$ contrast-enhanced computed tomography, $\mathbf{C}$ overview of chest $\mathrm{X}$-ray in p. a. and $\mathbf{D}$ lateral projection).

Abb. 2 Hämoptysen nach Therapie eines Oberlappen-Lungenemphysems mittels endobronchialer Spiralen (EBRC) mit Hypervaskularisationsarealen im linken paramediastinalen Oberlappen (A DSA linker Truncus intercostobronchialis, B KM-CT,
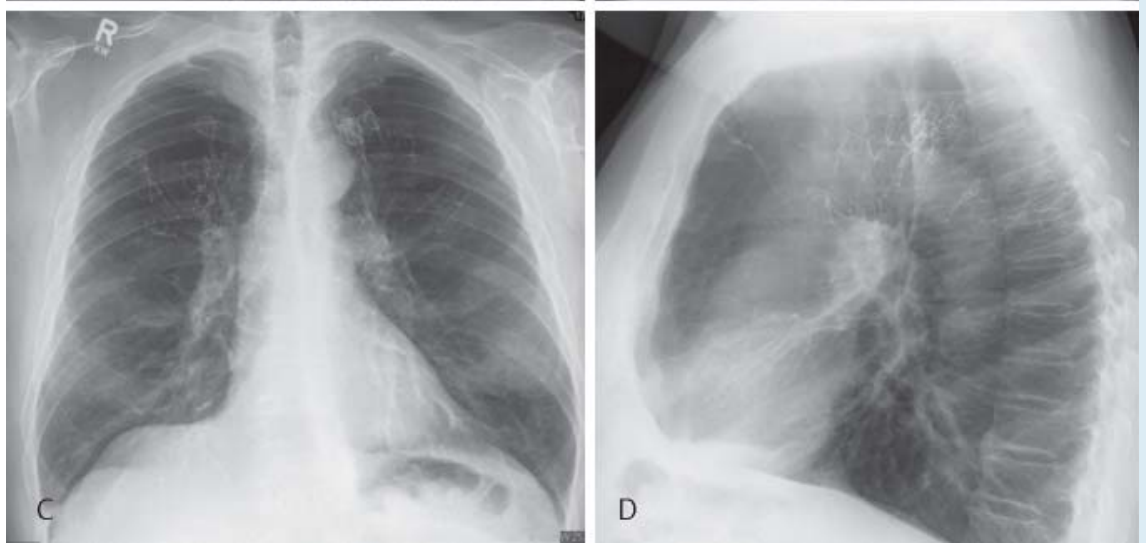

C Thorax-Übersicht p. a. und $\mathbf{D}$ lateral).

Currently bronchial artery embolization is the therapy of choice for the treatment of massive and recurring hemoptysis [12, 59]

\section{Diagnosing hemoptysis \\ $\nabla$}

In clinical routine, the two main diagnostic objectives in cases of hemoptysis are localization and identification of the cause of bleeding. Methods for this include a sputum analysis, hemostasis laboratory, bronchoscopy as well as chest X-ray as a thoracic overview radiograph on 2 planes or a contrast-enhanced multislice computed tomography (MSCT) with CT angiogram of the thorax. The sputum should be examined for the presence of bacteria (especially mycobacteria and fungus) as well as for malignant cells [16].

The hemostasis laboratory provides insight into the patient's cellular and plasmatic coagulation situation.

A promptly performed bronchoscopy (BSK) supports finding the cause and side localization of the bleeding [16, 60], although correct side localization of the bleeding can be achieved in only about half the patients [58, 61]. This can be performed easily and quickly as an initial fiber optic examination (fiber optic bronchoscopy - FOB) and as a rigid bronchoscopy in the case of more massive hemoptysis. Even in cases of heavy hemorrhaging, this can ensure a better overview, improved conditions for hemostasis, and oxygenation via jet ventilation. An advantage of bronchoscopy is the possibility of applying vasoactive substances to stanch the bleeding. The disadvantages of bronchoscopy in an acute bleeding situation include poor visibility due to endobronchial blood and the frequently ineffective therapeutic options $[16,58]$. Additional risks of bronchoscopy include air passage restriction by the bronchoscope, respiratory depression resulting from sedation, hypoxemia, as well as time lost until a definitive therapy can be found.
The typical chest X-ray should be a thoracic overview image in 2 planes in order to detect frequent causes such as pneumonia, pulmonary abscesses, bronchial carcinoma or acute or chronic pulmonary tuberculosis.

Compared to bronchoscopy, a conventional thoracic X-ray examination can obtain additional information in about only half of patients [62]. Today, a thoracic CT scan should be performed in addition to bronchoscopy, due to the improved information that imaging technology can provide to localize bleeding (63-100\% accuracy in identifying the proper lobe) $[61,63]$, as well as to disclose the cause of hemoptysis. This is supported by low-dose acquisition methods (automatic tube current modulation(ATCM)) for longitudinal and angle modulation $[64,65]$ and iterative image reconstruction methods (e.g. iDose ${ }^{4}$ (Philips), ADMIRE/SAFIRE/IRIS (Siemens), ASIR (GE). Compared to a standard thorax image on 2 planes with an effective dose of $0.1-0.2 \mathrm{mSv}$, a thoracic CT examination can be performed with an effective dose of $0.5-1.5 \mathrm{mSv}$ [66 - 71]. Further, this scan can be performed rapidly and promptly, a significant advantage in the case of marginally stable patients. Compared to a conventional X-ray, the added value of contrast-enhanced multidetector CT (MDCT) systems, optionally equipped with EKG triggering to minimize pulsation artifacts of the thoracic vessels consists in improved detection of bronchiectasis (in cases of COPD or CF), bronchial carcinoma, aspergilloma [62, 72], pulmonary arteriovenous malformations (PAVM) as well as aneurysms of the thoracic or pulmonary arteries. MDCT also provides useful information regarding the anatomy, origin and course of the bronchial arteries as well as the course of aberrant bronchial arteries [73, 74]. Improved visualization of pulmonary pathologies and surgical planning can be achieved using numerous post-processing techniques such as multiplanar reconstruction (MPR), maximum intensity projection (MIP) or 3-dimensional (3D) volume and surface displays (shaded surface display (SSD)). It has been demonstrated 
that a combination of bronchoscopy and MDCT provides the best results for the diagnosis of hemoptysis [63]. However, there is a question regarding the sequence of bronchoscopy and MDCT when diagnosing hemoptysis. Current studies indicate the advantages of performing MDCT prior to bronchoscopy [16, 75 - 77].

Conventional angiography using digital subtraction angiography (DSA) is utilized in the primary diagnosis of the bronchial arteries, however it is seldom used and is mainly employed for therapeutic bronchial artery embolization.

\section{Management of hemoptysis}

The management of hemoptysis primarily consists in monitoring and stabilizing the cardiopulmonary situation through correction of hypoxia, blood pressure stabilization and, if needed, substitution with blood products. In cases of massive hemoptysis, intensive monitoring of the patient and early endotracheal intubation (unilateral as needed) is preferred [1]. The therapeutic effectiveness of endobronchial installation of a cold saline solution, epinephrine or bronchial occlusion using a balloon catheter is limited $[1,60]$.

Until the 1970 s, in addition to bronchoscopic localization to one body side, the therapy of choice was resection of the bleeding pulmonary lobe; however the mortality rate of such intervention as an elective measure was $18.2 \%$, and under emergency conditions was as high as $40 \%$ due to the risk of hemorrhaging during surgery, asphyxia, bronchopleural fistulas or respiratory insufficiency $[5,78]$. Complicating this type of surgical intervention on patients with massive hemoptysis are pre-existing conditions and limited respiratory reserve. Surgical therapy remains the first choice in cases of iatrogenic pulmonary artery injury, thoracic trauma or therapy-resistant aspergilloma [16, 79].

\section{Interventional therapy}

$\nabla$

Although mild or moderate hemoptysis is frequently controlled using conservative therapy (antibiosis, discontinuation of nonsteroidal antibiotics (NSAID), or therapeutic bronchial artery embolization (installation of cold saline solution, vasoconstrictors), see Guidelines for CF Patients [50], bronchial artery embolization (BAE) is considered the method of choice in cases of both massive and recurring hemoptysis $[5,10,12,80]$, and should be undertaken promptly. In cases of hemoptysis with malignant origin (bronchial carcinoma, metastasis), bronchial artery embolization is strongly indicated, since the mortality rate among mild and degenerative patients (affecting $90 \%$ of patients) is significantly higher (21\%) that for hemoptysis with benign origin (5\%) [62, 81 - 83].

The goal of this approach is to reduce the systemic arterial perfusion pressure from the fragile bronchial arteries within the diseased lung parenchyma, thus stanching the bleeding [4]. When performing bronchial artery embolization, it should be noted that such patients usually suffer from chronic pulmonary disease and with dyspnea which can significantly worsen in a horizontal lying position (for angiography) and as a result of the hemoptysis. It must be further taken into account that the procedure must be repeatedly interrupted by the necessity to clear the airways due to expectorated blood. Although it is useful to use an oxygen mask for oxygenation of the patient during bronchial artery embolization, in individual cases selective intubation in the main bronchus contralateral to the bleeding is necessary to keep the airways open.

A neurological examination should be performed prior to bronchial artery embolization. Further, during the intervention, monitoring of the motor and sensory functions of the lower extremities should be ensured. Studies have shown that spinal complications resulting from $\mathrm{BAE}$ (e.g. ischemia) can be detected by highly-sensitive monitoring of somatosensory evoked potentials (SSEPs) [84]. Moderate sedation and administration of anxiolytics to the patient can facilitate the bronchial artery embolization, but should not impair the respiratory function, response and communication skills.

\section{Technology}

In general BAE should be performed by a radiologist experienced in intervention and embolization techniques in a clinic with a high-resolution digital subtraction angiography (DSA) unit.

Under sterile conditions and after local anesthesia of one groin, a 5 -French $(F)$ vascular sheath is introduced via a transfemoral access route. By means of a suitable $4 \mathrm{~F}$ or $5 \mathrm{~F}$ catheter (e.g. pigtail catheter) placed in the proximal descending aorta, thoracic overview images are acquired using digital subtraction angiography (DSA) using mechanical contrast agent injection (e.g. iodinebased contrast agent, injection quantity: $30 \mathrm{ml}$, injection flow: $20 \mathrm{ml} / \mathrm{second}$ ). Several projections should be acquired (anteriorposterior, left anterior oblique (LAO) and right anterior oblique (RAO)) to obtain a systematic representation of the bronchial arterial outlets from the aorta. Then following the Seldinger technique, using a 0.035 guide wire, the ostia of all bronchial arteries are located with an appropriate $4 \mathrm{~F}$ or $5 \mathrm{~F}$ catheter (Cobra, Mikaelsson, Simmons, Shepherd Hook, Headhunter, Sidewinder or SOS Omni) and displayed using a selective DSA with manual injection of approx. 5-6 ml contrast agent. The ostium of the right bron-

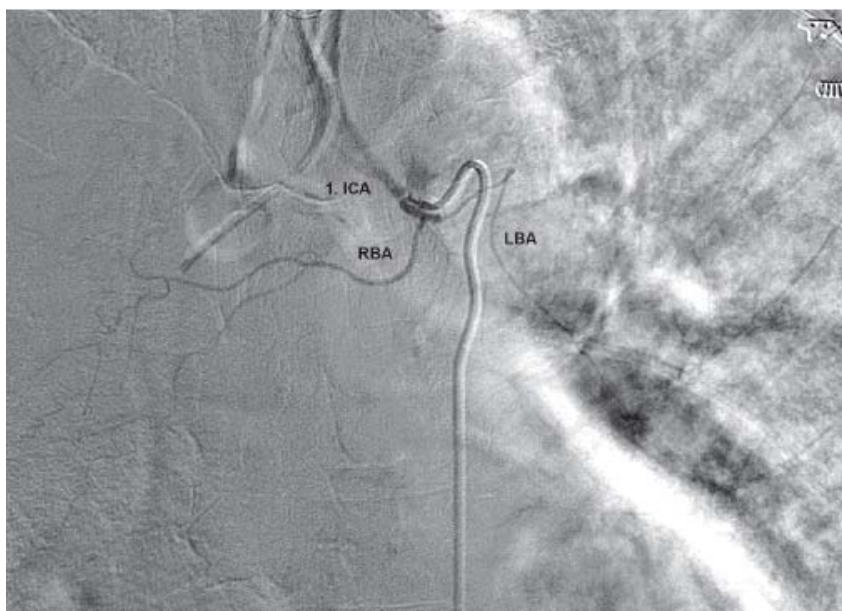

Fig. 3 Normal bronchial arteries with vessel diameters up to $1.5 \mathrm{~mm}$. As a variant the right (RBA) and left BA (LBA) origin from a common trunk from the aorta and directly adjacent, the origin of the 1st intercostal branch (1st ICA). (Intubated intensive care patient with blocked balloon catheter in the right main bronchus due to right endobronchial lung bleeding).

Abb.3 Normale Bronchialarterien mit Gefäßdiametern bis 1,5 mm. Als Normvariante kommuner Abgang der rechten (RBA) und linken BA (LBA) aus der Aorta und rechts unmittelbar benachbart aus der Aorta abgehender 1. Interkostalast (1. ICA). (Intensivpflichtiger, intubierter Patient mit geblocktem Ballonkatheter im rechten Hauptbronchus bei rechtsseitiger endobronchialer Lungenblutung). 

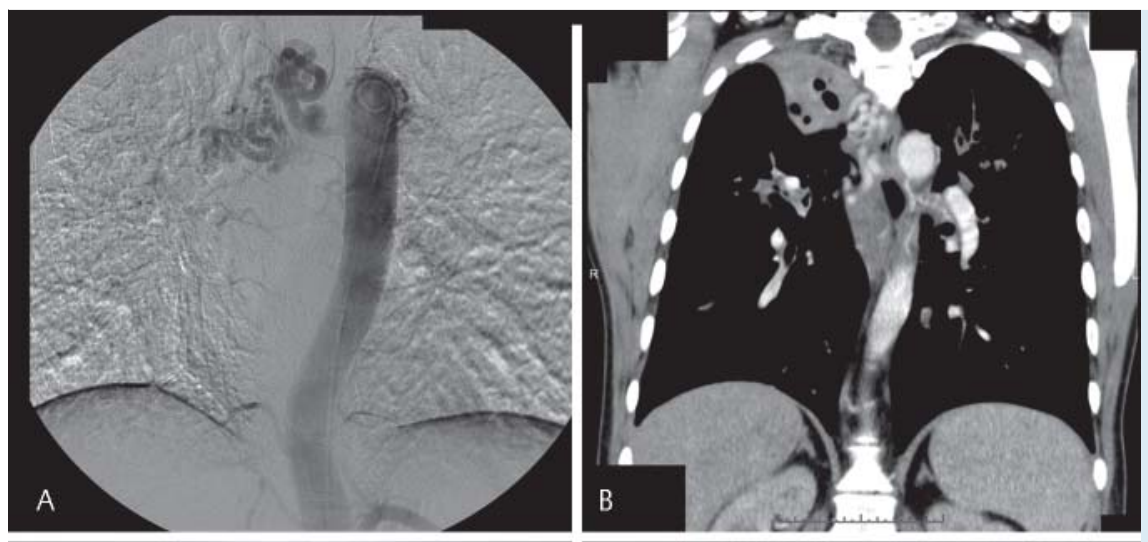

Fig. 4 Pathologically dilated BA of a patient with cystic fibrosis (CF). As the result of chronic inflammation of the bronchial wall, the right $\mathrm{BA}$ is enlarged and elongated as demonstrated by angiography $\mathbf{A}$, with contrast-enhanced computed tomography (CECT) in coronal reconstruction $\mathbf{B}$, as well as typical chest $\mathrm{X}$-ray $\mathbf{C}$ with pronounced bronchiectasis in the CECT $\mathbf{D}$.

Abb. 4 Pathologisch erweiterte BA eines Patienten mit Mukoviszidose (CF). Infolge der chronischen Bronchialwandinflammation Ektasie und Elongation der rechten BA in der DSA $\mathbf{A}$, in der KM-CT in koronarer Rekonstruktion B sowie typisches Röntgenübersichtsbild des Thorax $\mathbf{C}$ mit ausgeprägten
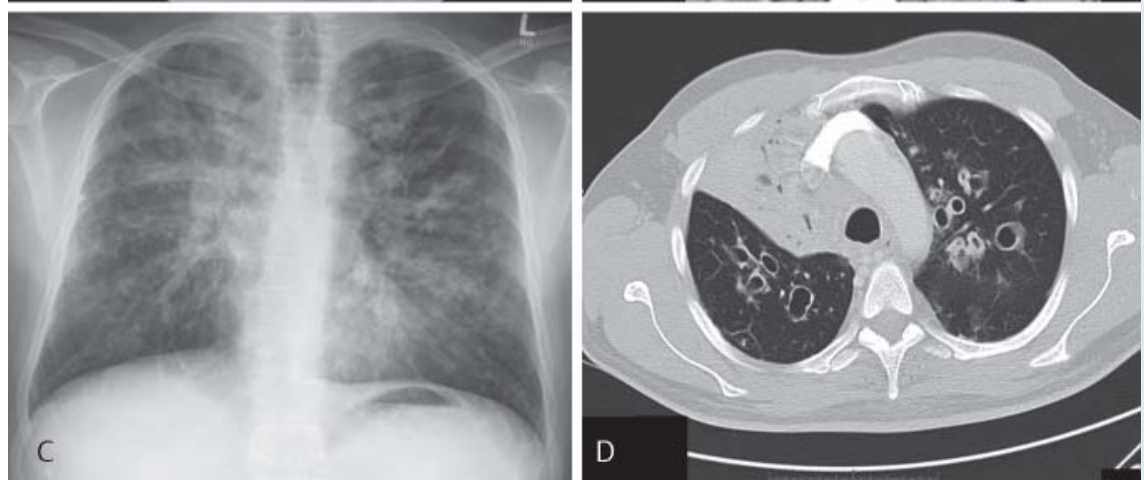
Bronchiektasien in der KM-CT D.

chial artery or right ICBT generally originate ventromedially from the descending aorta. The left bronchial artery typically originates ventrally from the descending aorta at the level of the 4th8 th thoracic vertebra. As described above, the ICBT is the most frequent source of branches supplying the spine [17]. In addition to avoiding direct occlusion of the ICBT by the catheter itself, the use of small quantities of low osmolar contrast agent reduces the risk of spinal ischemia $[12,45]$.

Selective display of the bronchial arteries ( $\bullet$ Fig. 3) can assess the potential for a possible source of bleeding of the bronchial artery as well as identifying possible branches supplying the spine. Active bleeding which can be recognized by extravasation from a branch of the bronchial artery can be demonstrated in about $3.6-10.8 \%$ of cases and then only during an episode of massive hemoptysis $[61,85,86]$. The diameter of the bronchial arteries in cases of chronic inflammatory pulmonary disease is generally between $2-3 \mathrm{~mm}$ [17], however it can be several millimeters, especially in patients with cystic fibrosis ( $\bullet$ Fig. 4). Indicators of a diseased bronchial artery and source of hemoptysis include expansion of the bronchial artery diameter over $2 \mathrm{~mm}$, a highly torturous course of the bronchial artery, the presence of systemic pulmonary arterial or venous shunts, contrast agent extravasation, hypervascularization zones or aneurysms [12, 85, 87]. Upon indisputable identification of a pathologically altered bronchial artery, the artery should be embolized after excluding branches supplying the spine or contrasting the anterior spinal arteries, and after risk assessment of a possible systemic embolism in bronchial arterial-pulmonary venous or pulmonary arterial shunts ( $\bullet$ Fig. 5). To ensure a stable position and safe application of the bronchial artery embolization material distal to the arteries supplying the spine, a coaxial technique is employed using a $4 \mathrm{~F}$ or $5 \mathrm{~F}$ guidance catheter positioned securely in the ostium of the bronchial artery through which a $2-3 F$ microcatheter system is introduced as distally as possible into the artery $[4,5]$. Due to

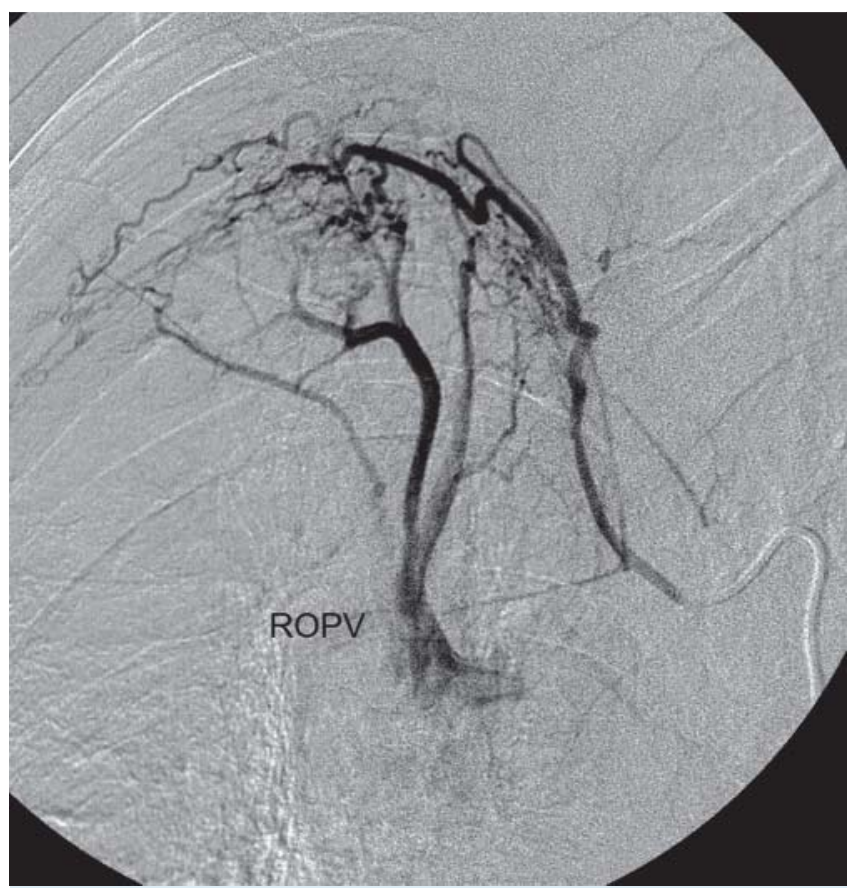

Fig. 5 Right bronchial artery (RBA) from a common intercostobronchial trunk with strong vascular shunts between the RBA and the pulmonary veins of the right upper lobe (RUPV).

Abb.5 Rechte Bronchialarterie aus einem Truncus intercostobronchialis mit kräftigen Shunts zu den Pulmonalvenen des rechten Oberlappens (ROPV).

elongation of the bronchial artery and normal variation, the distance of the outlets of spinal branches measured from their aortal origin vary substantially, so that no general recommendation can 

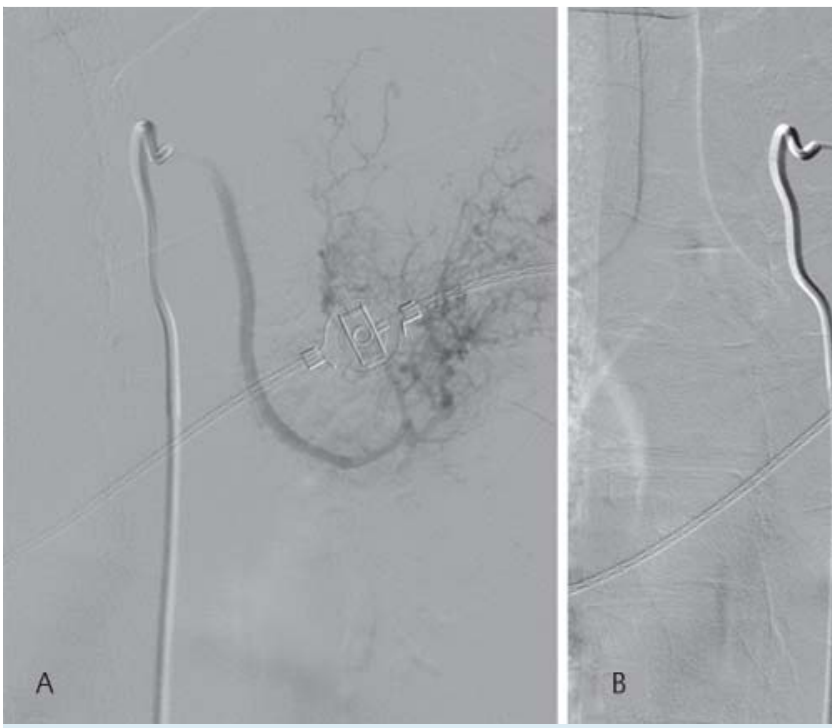

Fig. 6 Left bronchial artery in a patient with left central bronchial carcinoma targeted with a $5 \mathrm{~F}$ Mikaelsson catheter $\mathbf{A}$, coaxial placement of a $2.4 \mathrm{~F}$ micro catheter $\mathbf{B}$ and after selective embolization with PVA particles (peripheral) and micro embolization coils (proximal) with complete devascularization of the tumor and suspended blood flow in the left BA C.

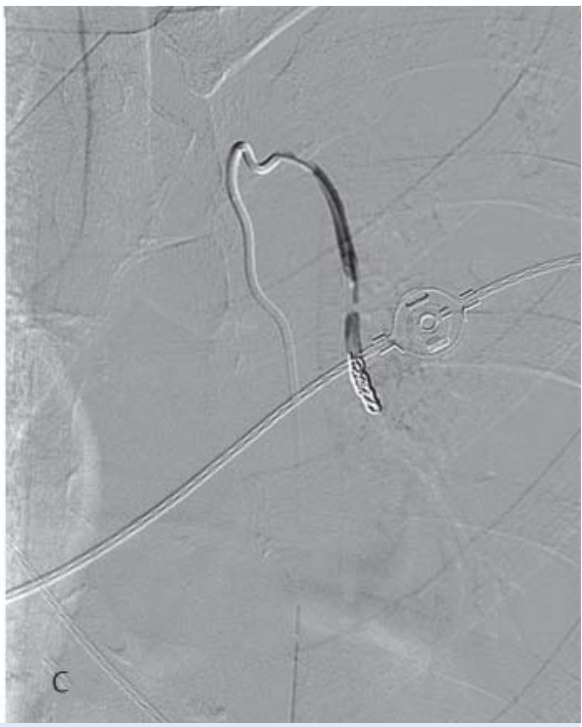

Abb. 6 Linke Bronchialarterie bei einem links-hilären BC nach Sondierung mittels eines $5 \mathrm{~F}$ Mikaelsson-Katheters A, koaxialem Einwechseln eines 2,4F Mikrokatheters B und nach selektiver Embolisation mittels PVA-Partikeln (peripher) und Mikroembolisationsspiralen (proximal) mit Devaskularisation des Tumors und Sistieren des Blutflusses in der linken BA C.
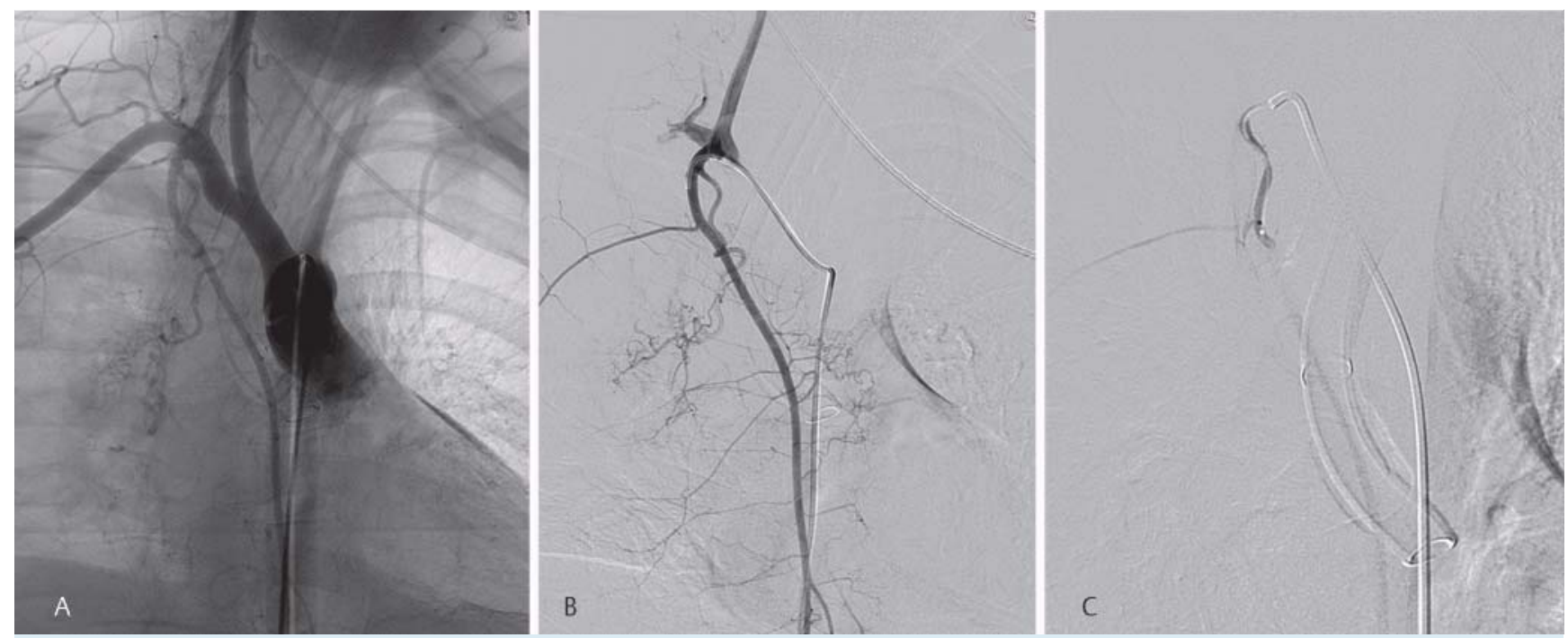

Fig. 7 Extrabronchial origin of the right BA from the proximal right internal mammary artery (RIMA) in angiogram A, selective DSA of the RIMA B and after particle embolization of the right BA with suspended blood flow $C$.

Abb. 7 Extrabronchialer Ursprung einer rechten BA aus der proximalen rechten A. mammaria interna (RIMA) in der Aortographie A, nach selektiver DSA der RIMA B und nach Partikelembolisation der rechten BA mit sistierendem Blutfluss C.

be made with respect to the depth of the microcatheter probing into the bronchial artery to reach a safe application site; consequently this must be determined individually [88]. It must also be emphasized that spinal branches cannot be visualized prior to selective BAE, and can only become visible in the course of embolization as a result of blood flow redistribution [88-90]. After selective DSA of the bronchial artery using manual injection of a contrast agent $(1-2 \mathrm{ml})$ and careful avoidance of the blood vessels feeding the spine distal to the end of the catheter (particularly ICBT on the right side) a bronchial artery embolization should be performed, taking into account the clinical, bronchoscopic, CT and angiographic findings ( $\boldsymbol{0}$ Fig. $\mathbf{6}$ ). In the course of this procedure, reflux of embolisate into the aorta or branches supplying the spine with consecutive arterial misembolization must absolutely be avoided. This risk can be reduced by means of an incremental BAE with intermittent selective control DSA via the microcatheter $[88,90]$. A bronchial artery embolization is successful if more than $95 \%$ of the peripheral vascular branches have been embolized or if retrograde blood flow within the bronchial artery has been suspended [91].

The additional DSA of both subclavian arteries as well as of the lower thoracic aorta with the phrenic arteries (in cases of lower 
lobe manifestations) excludes transpleural collaterals from aberrant bronchial arteries as a source of bleeding ( $\bullet$ Fig. 7).

A subsequent thoracic aortogram with no contrasting of arterial branches supplying the lung is indicative of a successful BAE.

If, despite successful bronchial artery embolization of all arterial feeders or in the case of normal, non-pathologically configured pulmonary arteries, continued or recurrent hemoptysis appears, then evaluation of the pulmonary arterial circulatory pathway is necessary [47] in order to rule out pulmonary arterial aneurysms or pulmonary arteriovenous malformations (PAVM) which are present in $5-10.5 \%$ of cases of hemoptysis [59, 92, 93]. The primary cause of bleeding from the pulmonary arterial circulatory area is Rasmussen's aneurysm which is a pseudoaneurysm of an arrosion of a peripheral pulmonary artery resulting from chronic inflammation, typically cases of chronic exudative cavernous pulmonary tuberculosis. Diagnosis is best achieved using a con- trast-supported CT which shows contrast agent-enriched nodules and aneurysms in the wall of a tubercular cavern [94].

\section{Embolization material}

There are numerous options regarding material used for bronchial artery embolization or blockage of PAVM ( $\bullet$ Table 2 ).

In the $1980 \mathrm{~s}$ and $1990 \mathrm{~s}$, surgical gelatin sponges (Gelfoam) were employed since they are quite inexpensive and easy to use, but often cause only temporary occlusion due to resorption. Currently initial embolization preferably utilizes flow-directed, nonresorbable, permanently occluding polyvinyl alcohol-based (PVA) particles larger than 250 microns or cross-linking gelatin particles (tris-acryl gelatin microspheres (TAGM) [12, 95-98] ( $\bullet$ Fig. 8). Due to its more uniform diameter and hydrophilic surface, TAGM exhibits less clumping and microcatheter occlusion [98]. It was shown that the 12-month success rate, i.e. suppres-

Table 2 BAE embolization material.

\begin{tabular}{|c|c|c|c|c|c|}
\hline particle embolisate & form & vessel blockage & size $[\mu \mathrm{m}]$ & trade name & source \\
\hline gelatin sponge & $\begin{array}{l}\text { amorphous, manually } \\
\text { configurable }\end{array}$ & temporary & $\begin{array}{l}\text { variable } \\
(>500)\end{array}$ & Gelfoam ${ }^{\circledR}$ & $\begin{array}{l}\text { Baxter Health- } \\
\text { care Corporation }\end{array}$ \\
\hline PVA foam particle & irregular & \multirow[t]{8}{*}{ permanent } & $90-2800$ & $\begin{array}{l}\text { PVA foam embo- } \\
\text { lization particles }\end{array}$ & Cook Medical \\
\hline polyvinyl alcohol(PVA) particles & irregular amorphic & & $45-1180$ & Contour $^{\circledR}$ & $\begin{array}{l}\text { Boston Scientific } \\
\text { Cooperation }\end{array}$ \\
\hline starch particles & spherical & & 50 & EmboCept $^{\circledR}$ & PharmaCept \\
\hline PVA particles & spherical & & $100-1200$ & Contour SE ${ }^{\circledR}$ & $\begin{array}{l}\text { Boston Scientific } \\
\text { Cooperation }\end{array}$ \\
\hline PVA hydrogel particles & spherical & & $100-700$ & LC Bead $^{\circledR}$ & AngioDynamics \\
\hline PVA hydrogel particles & spherical & & $100-1200$ & Bead Block ${ }^{\circledR}$ & Terumo \\
\hline Tris-acryl gelatin microspheres (TAGM) & spherical & & $40-1200$ & Embospheres $^{\circledR}$ & $\begin{array}{l}\text { Merrit Medical } \\
\text { Systems }\end{array}$ \\
\hline hydrogel particles with Polyzene ${ }^{\circledR}-\mathrm{F}$ coating & spherical & & $40-1300$ & Embozene $^{\circledR}$ & $\begin{array}{l}\text { CeloNova Bio- } \\
\text { Sciences }\end{array}$ \\
\hline embolization coils & & & size [mm] & & \\
\hline $\begin{array}{l}\text { stainless steel } \\
\text { („stainless steel“) }\end{array}$ & \multirow[t]{3}{*}{$\begin{array}{l}\text { straight, helical, dou- } \\
\text { ble-helical, } 3 \text { D }\end{array}$} & \multirow[t]{3}{*}{ permanent } & $2-20 \mathrm{~mm}$ & & \\
\hline nitinol & & & & & \\
\hline platinum & & & & & \\
\hline
\end{tabular}
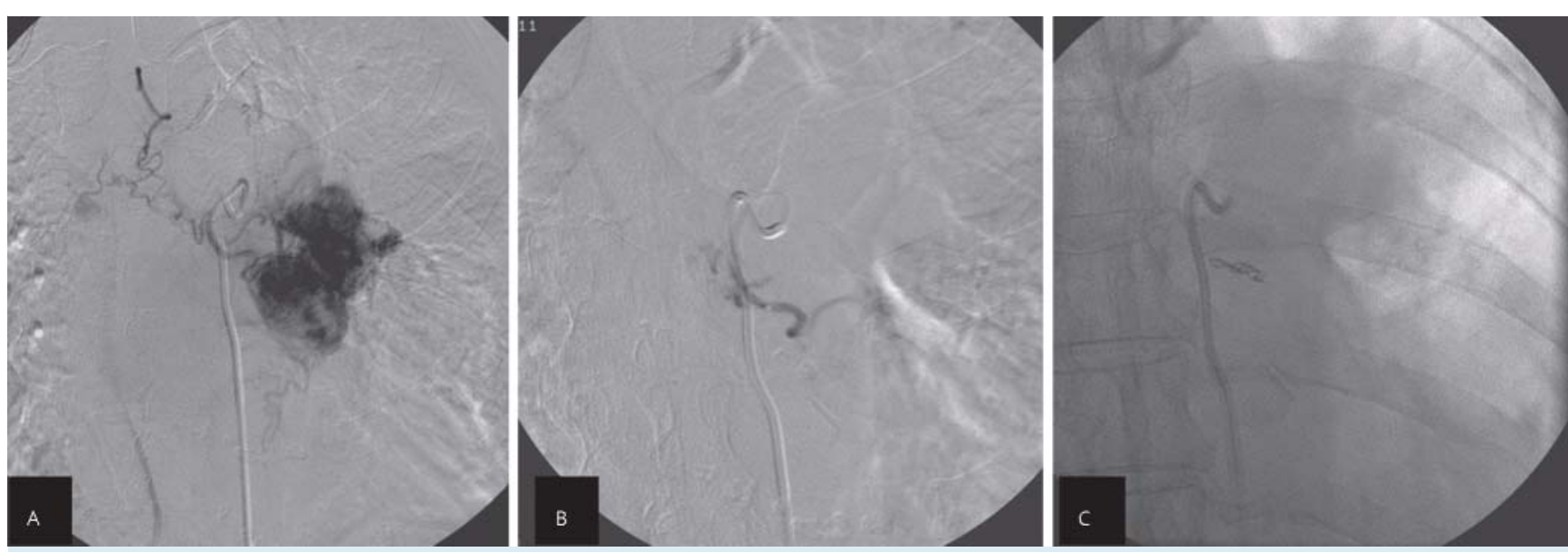

Fig. 8 Left bronchial artery in a patient with left pulmonary hypervascularized metastases of a thyroid carcinoma before and after peripheral PVA particle and proximal micro coil embolization.

Abb. 8 Linke Bronchialarterie bei links-pulmonalen hypervaskularisierten Metastasen eines Schilddrüsenkarzinoms vor und nach PVA-Partikel- sowie proximaler Mikrospiralen-Embolisation. 
sion of recurrent hemoptysis resulting from using PVA particles (355-500 $\mu \mathrm{m}$ and $500-710 \mu \mathrm{m}$ ) compared to gelatin sponges (1 $\left.(\mathrm{mm})^{3}\right)$ is significantly greater (62-63\% vs. $45 \%$ ) [99]. However, the technical and primary success rate (up to 1 month post-BAE) for both particle types did not differ [99]. In this study, results were not dependent on particle size $(355-500 \mu \mathrm{m}$ vs. $500-$ $710 \mu \mathrm{m}$ ). In addition, particles $>350 \mu \mathrm{m}$ appeared to reduce the risk of spinal complications, since they were too large to be used for embolization of small vessels supplying the spine [58]. In experimental studies smaller particles $(<250 \mu \mathrm{m})$ or the use of ethanol frequently lead to bronchial wall necrosis resulting from a blockage of the bronchopulmonary anastomoses and subsequent obstruction of capillary perfusion of the bronchial walls [100-102]. Given the shared vascular supply to the esophagus or pulmonary arterial walls and aorta via the bronchial arteries, there is a risk of disastrous necrosis of the walls of the esophagus, pulmonary arteries and aorta [4]. The use of N-butyl-2-cyanoacrylate (NBCA (Histoacryl $\left.{ }^{\circledR}\right)$ ) is the subject of controversy in the literature. In earlier studies an increased risk of misembolization was attributed to liquid embolization material due to uncontrolled reflux or remnants of NBCA on the catheter tip [103, 104]; however, current studies have shown that liquid materials exhibit better long-term occlusion of the bronchial arteries without an increased rate of complications compared to PVA particles (non-recurrence of hemoptysis 5 years post BAE: $83 \%$ vs. $66 \%$ ) [105]. In this case, NBCA was diluted in a ratio of $1: 2$ to $1: 4$ with iodinated oily X-ray contrast agent Lipiodo ${ }^{\circledR}$ and applied superselectively. Although the authors refer to the potential risks of a liquid embolisate, they could not ascertain this in their study of the practical employment of NBCA for bronchial artery embolization. Increased rates of post-BAE complications such as bronchial or aortic wall necrosis, pulmonary parenchymal ischemia could likewise not be established [103-106]. However, it should be emphasized that when using liquid embolisates such as NBCA, extreme caution should be exercised, and that the risk of misembolization, particularly in spinal branches can be significantly increased if the interventionist is insufficiently experienced.

Due to their size, embolization coils cause proximal occlusion of the bronchial artery. In the event of recurrent bronchial artery hemoptysis, this can obstruct reintervention into the periphery of the BA (e.g. repeated particle embolization) if there is reconstitution and perfusion of the pulmonary artery vascular bed by mediastinal or bronchial collaterals. PAVMs should be treated with targeted removable stainless steel embolization coils or balloons, analogous to the treatment of Rasmussen aneurysms in which the afferent pulmonary artery feeders are closed off [107-111].

\section{Conclusions \\ $\nabla$}

The goal of the treatment of life-threatening massive hemoptysis is to control and stop bronchial artery bleeding. Numerous studies have proven the effectiveness and success of bronchial artery embolization. In recent decades the primary success rate of BAE has been continuously increased by improvements of catheter and embolization material so that in this time period the success rate up to 1 month post-BAE is $73-99 \%$ (৫ Table 3 ). On the other hand, in the longer term, lower BAE success rates for the treatment of hemoptysis have been recorded. Thus, studies of the 1 46 month post-treatment time frame show a recurrence of hemoptysis in $10-55 \%$ of cases ( Table 3 ). However, it should be
Table 3 Success and recurrence rate after BAE (from Chun et al. [90]).

\begin{tabular}{|lllll|}
\hline authors & year & $\begin{array}{l}\text { number of } \\
\text { patients }\end{array}$ & $\begin{array}{l}\text { immediate } \\
\text { success rate } \\
\text { (up to 1 month } \\
\text { post-BAE) in \% }\end{array}$ & $\begin{array}{l}\text { recurrence } \\
\text { rate }\end{array}$ \\
\hline Remy et al. [10] & 1977 & 49 & $84 \%$ & $28.6 \%$ \\
\hline Rabkin et al. [37] & 1987 & 306 & $90.8 \%$ & $33.7 \%$ \\
\hline Hayakawa et al. [68] & 1992 & 58 & $86.2 \%$ & $28 \%$ \\
\hline Ramakantan et al. [61] & 1996 & 140 & $73 \%$ & $27.1 \%$ \\
\hline Mal et al. [14] & 1999 & 56 & $77 \%$ & $55.3 \%$ \\
\hline Swanson et al. [91] & 2002 & 54 & $94 \%$ & $24.1 \%$ \\
\hline Poyanli et al. [58] & 2007 & 140 & $98.5 \%$ & $10 \%$ \\
\hline Lee et al. [92] & 2008 & 70 & $99 \%$ & $26 \%$ \\
\hline Chun et al. [79] & 2009 & 50 & $86 \%$ & $28 \%$
\end{tabular}

kept in mind that although bronchial artery embolization successfully treats hemoptysis as a symptomatic intervention, it cannot eliminate the underlying cause. For this reason, causal therapy after a successful BAE is required to ensure the long-term success of the embolization. Depending upon the source of the hemoptysis, therapy can include antibiotics (for TB, aspergillo$\mathrm{ma}$ ), or elective surgical local resection (for bronchial carcinoma, chronic TB, aspergilloma) $[95,112]$. Aspergilloma, in particular, may have poor outcomes with recurrent bleeding rates of up to $100 \%$ and $50 \%$ mortality rates within the first month after bronchial artery bleeding [113]. Therefore after repeated bronchial artery embolization, aggressive surgical approaches should be used to eliminate infection $[11,114-116]$. If this does not succeed, recurrence of hemorrhaging within $2-5$ years is highly likely [15.113]. Recurrent hemoptysis after BAE can be caused pathomechanically by incomplete embolization, recanalization of the embolized bronchial artery, collateralization by other arterial vascular territories, inadequate causal therapy or progression of the underlying pulmonary disease $[3,4,59,95,114]$. It should be emphasized that all possible blood vessels supporting bronchial artery bleeding must be identified and embolized, especially including extrabronchial systemic arterial and pulmonary arterial vessels. It must also be stressed that the avoidance of recurrent hemoptysis is not the sole clinical success parameter. A retrospective study showed that adult patients receiving bronchial artery embolization following recurrent or massive hemoptysis exhibited significantly reduced pulmonary function with an increased transplant rate as well as higher mortality without recurrent massive hemoptysis compared to patients who had not undergone BAE [117].

\section{Complications \\ $\nabla$}

Due to the collateral circulation of the bronchial arteries in other tissue territories (esophagus, visceral pleura, vasa vasorum of the aorta, pulmonary arteries and veins, and particularly the spinal arteries) misembolization can have fatal results. The most frequent side effects of BAE are transient chest pain (24-91\%) and/ or dysphagia $(0.7 \%-18.2 \%)[86,118,119]$ probably caused by occlusion of intercostal or esophageal branches. The subintimal short segment dissection of the aorta or bronchial artery has been indicated with a prevalence of 1 to $6.3 \%$, but is frequently non-symptomatic, and generally requires no additional remedies $[11,12,14,15,96]$. A particularly feared complication, generally 
based on the toxicity of the contrast agent formerly in use, is transverse myelitis caused by spinal cord ischemia as a consequence of embolization of spinal branches or particle embolization in the vicinity of the ostium with aorto-spinal particle dislocation. A prevalence of $1.4-6.5 \%$ has been reported [14, 86, 88, $89,97]$. The risk of this type of spinal event is significantly reduced by a superselective BAE of terminal bronchial artery branches distal to vessels supporting the anterior spinal arteries [97]. Necrosis of the bronchial or aortic walls, transient cortical blindness, ischemic colitis, pulmonary infarction or bronchial-esophageal fistulas are rare complications of BAE [101, 120 - 123].

\section{Summary \\ $\nabla$}

Hemoptysis represents a life-threatening pulmonary emergency and necessitates immediate diagnosis and therapy. Initial diagnosis using a conventional chest X-ray, contrast-supported multislice computer tomography (MSCT) with CT angiography (CTA) of the thorax as well as bronchoscopy are required to determine the cause of hemoptysis, side localization, detection of abnormal bronchial and extrabronchial vessel branches; these also serve to support planning of interventional endovascular intervention in the form of bronchial artery embolization (BAE). BAE has established itself as a first-line therapy for the treatment of massive and recurring hemoptysis or as a preparation for elective surgical therapy. Bronchial artery embolization should be considered a safe procedure when performed by an experienced endovascular interventionist with profound knowledge of potential pitfalls of the method. Recurrent hemoptysis after BAE is not unusual and likewise requires prompt embolization after investigation of endobronchial systemic or pulmonary bleeding sources.

\section{References}

1 Haponik EF, Fein A, Chin R. Managing life-threatening hemoptysis: has anything really changed? Chest 2000; 118: 1431 -1435

2 Crocco JA, Rooney JJ, Fankushen DS et al. Massive hemoptysis. Arch Intern Med 1968; 121: $495-498$

3 Najarian KE, Morris CS. Arterial embolization in the chest. J Thorac Imaging 1998; 13: 93-104

4 Marshall TJ, Jackson JE. Vascular intervention in the thorax: bronchial artery embolization for haemoptysis. Eur Radiol 1997; 7: 1221-1227

5 Fernando HC, Stein M, Benfield JR et al. Role of bronchial artery embolization in the management of hemoptysis. Arch Surg 1998; 133: $862-866$

6 Knott-Craig CJ, Oostuizen JG, Rossouw G et al. Management and prognosis of massive hemoptysis. Recent experience with 120 patients. J Thorac Cardiovasc Surg 1993; 105: 394-397

7 Gourin A, Garzon AA. Operative treatment of massive hemoptysis. Ann Thorac Surg 1974; 18: 52-60

8 Remy J, Voisin C, Ribet $M$ et al. Treatment, by embolization, of severe or repeated hemoptysis associated with systemic hypervascularization. Nouv Presse Med 1973; 2: 2060

9 Wholey MH, Chamorro HA, Rao G et al. Bronchial artery embolization for massive hemoptysis. JAMA 1976; 236: 2501 - 2504

10 Remy J, Arnaud A, Fardou H et al. Treatment of hemoptysis by embolization of bronchial arteries. Radiology 1977; 122: 33-37

11 Uflacker R, Kaemmerer A, Neves C et al. Management of massive hemoptysis by bronchial artery embolization. Radiology 1983; 146: 627-634

12 Uflacker R, Kaemmerer A, Picon PD et al. Bronchial artery embolization in the management of hemoptysis: technical aspects and long-term results. Radiology 1985; 157: 637-644

13 Keller FS, Rosch J, Loflin TG et al. Nonbronchial systemic collateral arteries: significance in percutaneous embolotherapy for hemoptysis. Radiology 1987; 164: 687-692
14 Mal H, Rullon I, Mellot F et al. Immediate and long-term results of bronchial artery embolization for life-threatening hemoptysis. Chest 1999; 115: $996-1001$

15 Kato A, Kudo S, Matsumoto K et al. Bronchial artery embolization for hemoptysis due to benign diseases: immediate and long-term results. Cardiovasc Intervent Radiol 2000; 23: 351 - 357

16 Jean-Baptiste E. Clinical assessment and management of massive hemoptysis. Crit Care Med 2000; 28: 1642 - 1647

17 Botenga AS. Broncho-bronchial anastomosis. A selective angiographic study. Ann Radiol (Paris) 1970; 13: 1-16

18 Williams JR, Wilcox WC, Burns RR. Angiography of the Systemic Pulmonary Circulation. Am J Roentgenol Radium Ther Nucl Med 1963; 90: 614-627

19 Neyazaki T. A method for arteriography of the bronchial artery. Jpn Heart J 1962; 3: $523-536$

20 Viamonte M Jr. Selective Bronchial Arteriography in Man; Preliminary Report. Radiology 1964; 83: 830-839

21 Reuter SR, Olin T, Abrams HL. Selective Bronchial Arteriography. Radiology $1965 ; 84: 87-95$

22 Newton TH, Preger L. Selective Bronchial Arteriography. Radiology 1965; 84: 1043 - 1051

23 Feigelson $\mathrm{HH}$, Ravin HA. Transverse myelitis following selective bronchial arteriography. Radiology 1965; 85: 663-665

24 Kardjiev V, Symeonov A, Chankov I. Etiology, pathogenesis, and prevention of spinal cord lesions in selective angiography of the bronchial and intercostal arteries. Radiology 1974; 112: $81-83$

25 Remy J, Voisin C, Dupuis C et al. Treatment of hemoptysis by embolization of the systemic circulation. Ann Radiol (Paris) 1974; 17: 5-16

26 Cauldwell EW, Siekert RG et al. The bronchial arteries; an anatomic study of 150 human cadavers. Surg Gynecol Obstet 1948; 86: 395-412

27 Pump KK. Distribution of bronchial arteries in the human lung. Chest 1972; 62: 447-451

28 Deffebach ME, Charan NB, Lakshminarayan S et al. The bronchial circulation. Small, but a vital attribute of the lung. Am Rev Respir Dis 1987; 135: $463-481$

29 Furuse M, Saito K, Kunieda E et al. Bronchial arteries: CT demonstration with arteriographic correlation. Radiology 1987; 162: 393-398

30 Lee ST, Kim SY, Hur G et al. Coronary-to-bronchial artery fistula: demonstration by 64-multidetector computed tomography with retrospective electrocardiogram-gated reconstructions. Journal of computer assisted tomography 2008; 32: 444-447

31 Lee CM, Leung TK, Wang HJ et al. Identification of a coronary-to-bronchial-artery communication with MDCT shows the diagnostic potential of this new technology: case report and review. J Thorac Imaging 2007; 22: $274-276$

32 Bas $S$, Yiginer $O$, Atalay $M$ et al. Coronary-to-bronchial artery fistula with conventional and multi-detector computed tomography angiographic images. Hellenic journal of cardiology: $\mathrm{HJC}=$ Hellenike kardiologike epitheorese 2010; 51: 164 - 165

33 Cho J, Shin T, Jun K et al. Transcatheter embolization of bronchial artery arising from left circumflex coronary artery in a patient with massive hemoptysis. Cardiovasc Intervent Radiol 2010; 33: 169-172

34 Moon MH, Kang JK, Song H. Acquired coronary-to-bronchial artery fistula after two valve surgeries. Asian cardiovascular \& thoracic annals 2014; $22: 478-480$

35 Eryilmaz U, Gungor H, Uyar S et al. Circumflex-to-bronchial artery fistula with saccular aneurysm. Postepy $\mathrm{w}$ kardiologii interwencyjnej = Advances in interventional cardiology 2013; 9: 296-297

36 Battal B, Saglam M, Ors F et al. Aberrant right bronchial artery originating from right coronary artery - MDCT angiography findings. Br J Radiol 2010; 83: e101-e104

$37 \mathrm{Oz} \mathrm{F}$, Erdogan I, Oflaz $\mathrm{H}$ et al. Bifid origin of the right coronary artery, coexisting with an anomalous right bronchial artery originating from the circumflex coronary artery. Anadolu kardiyoloji dergisi: AKD = the Anatolian journal of cardiology 2013; 13: E9-E10

38 Lee WH, Jung GS, Cho YD et al. Anomalous bronchial artery originating from the right coronary artery in a patient with angina (2009: 4b). Eur Radiol 2009; 19: 1822-1825

39 Van den Berg JC, Overtoom TT, De Valois JC. Case report: bronchial to coronary artery anastomosis-a potential hazard in bronchial artery embolization. Br J Radiol 1996; 69: 570-572

40 Peynircioglu B, Ergun 0 , Hazirolan $T$ et al. Bronchial to coronary artery fistulas: an important sign of silent coronary artery disease and potential complication during bronchial artery embolization. Acta Radiol 2007; 48: $171-172$ 
41 Miyazono N, Inoue H, Hori A et al. Visualization of left bronchial-to-coronary artery communication after distal bronchial artery embolization for bronchiectasis. Cardiovasc Intervent Radiol 1994; 17: 36-37

42 Lee WS, Lee SA, Chee HK et al. Coronary-bronchial artery fistula manifested by hemoptysis and myocardial ischemia in a patient with bronchiectasis. The Korean journal of thoracic and cardiovascular surgery 2012; 45: 49-52

43 Jiang S, Sun XW, Yu D et al. Aberrant left inferior bronchial artery originating from the left gastric artery in a patient with acute massive hemoptysis. Cardiovasc Intervent Radiol 2013; 36: 1420-1423

44 Jiang S, Sun XW, Jie B et al. Endovascular Embolization of an Aberrant Bronchial Artery Originating from the Vertebral Artery in a Patient with Massive Hemoptysis. Cardiovasc Intervent Radiol 2013; DOI: $10.1007 /$ s00270-013-0778-9

45 Di Chiro G. Unintentional spinal cord arteriography: a warning. Radiology $1974 ; 112: 231-233$

46 Malik AB, Tracy SE. Bronchovascular adjustments after pulmonary embolism. J Appl Physiol Respir Environ Exerc Physiol 1980; 49: 476 - 481

47 Ferris EJ. Pulmonary hemorrhage. Vascular evaluation and interventional therapy. Chest 1981; 80: 710-714

$48 \mathrm{McDonald}$ DM. Angiogenesis and remodeling of airway vasculature in chronic inflammation. Am J Respir Crit Care Med 2001; 164: S39-S45

49 Liebow AA, Hales MR, Lindskog GE. Enlargement of the bronchial arteries, and their anastomoses with the pulmonary arteries in bronchiectasis. Am J Pathol 1949; 25: 211 - 231

50 Flume PA, Mogayzel PJ Jr et al. Cystic fibrosis pulmonary guidelines: pulmonary complications: hemoptysis and pneumothorax. Am J Respir Crit Care Med 2010; 182: 298-306

51 Davidoff $A B$, Udoff EJ, Schonfeld SA. Intraaneurysmal embolization of a pulmonary artery aneurysm for control of hemoptysis. Am J Roentgenol Am J Roentgenol 1984; 142: 1019-1020

52 Watanabe H, Numata T, Yanai $H$ et al. Bronchial artery aneurysm diagnosed on 3D-CT. Internal medicine 2014; 53: 1451 - 1452

53 Tan AK, Thirugnanam A. Giant bronchial artery aneurysm presenting as a right hilar mass. Asian cardiovascular \& thoracic annals 2013; 21: $227-230$

54 Patel R, Uchida D, Feola GP et al. Bronchial Artery Pseudoaneurysm as an Unsuspected Cause of Hemoptysis in a Pediatric Patient. The Annals of otology, rhinology, and laryngology 2014; 123: 591 - 595

55 Morais F, Mascarenhas VV, Campos P. Ruptured bronchial artery aneurysm in patient with unknown trauma or lung disease. Revista portuguesa de pneumologia 2014; 20: 117

56 Kaufman C, Kabutey NK, Sgroi M et al. Bronchial artery pseudoaneurysm with symptomatic mediastinal hematoma. Clinical imaging 2014; 38: $536-539$

57 Hori D, Noguchi K, Nomura Y et al. Successful endovascular treatment of ruptured bronchial artery aneurysm. Asian cardiovascular \& thoracic annals 2013; 21: 615-617

58 Yoon W, Kim JK, Kim YH et al. Bronchial and nonbronchial systemic artery embolization for life-threatening hemoptysis: a comprehensive review. Radiographics 2002; 22: 1395 -1409

59 Rabkin JE, Astafjev VI, Gothman LN et al. Transcatheter embolization in the management of pulmonary hemorrhage. Radiology 1987; 163 : $361-365$

60 Dweik RA, Stoller JK. Role of bronchoscopy in massive hemoptysis. Clin Chest Med 1999; 20: 89-105

61 Hsiao EI, Kirsch CM, Kagawa FT et al. Utility of fiberoptic bronchoscopy before bronchial artery embolization for massive hemoptysis. Am J Roentgenol Am J Roentgenol 2001; 177: 861 - 867

62 Hirshberg B, Biran I, Glazer $M$ et al. Hemoptysis: etiology, evaluation, and outcome in a tertiary referral hospital. Chest 1997; 112: $440-444$

63 Abal AT, Nair PC, Cherian J. Haemoptysis: aetiology, evaluation and outcome-a prospective study in a third-world country. Respir Med 2001; 95: $548-552$

64 Kalra MK, Maher MM, Toth TL et al. Techniques and applications of automatic tube current modulation for CT. Radiology 2004; 233: 649- 657

65 Schindera ST, Nelson RC, Yoshizumi T et al. Effect of automatic tube current modulation on radiation dose and image quality for low tube voltage multidetector row CT angiography: phantom study. Academic radiology 2009; 16: $997-1002$

66 Lee $Y$, Jin $K N$, Lee NK. Low-dose computed tomography of the chest using iterative reconstruction versus filtered back projection: comparison of image quality. Journal of computer assisted tomography 2012; 36: $512-517$
67 Katsura M, Matsuda I, Akahane $M$ et al. Model-based iterative reconstruction technique for ultralow-dose chest CT: comparison of pulmonary nodule detectability with the adaptive statistical iterative reconstruction technique. Investigative radiology 2013; 48: 206-212

68 Baumueller S, Winklehner A, Karlo C et al. Low-dose CT of the lung: potential value of iterative reconstructions. Eur Radiol 2012; 22: 2597 - 2606

69 Neroladaki A, Botsikas D, Boudabbous S et al. Computed tomography of the chest with model-based iterative reconstruction using a radiation exposure similar to chest X-ray examination: preliminary observations. Eur Radiol 2013; 23: 360 - 366

70 Prakash P, Kalra MK, Ackman JB et al. Diffuse lung disease: CT of the chest with adaptive statistical iterative reconstruction technique. Radiology 2010; 256: 261 - 269

71 Prakash P, Kalra MK, Digumarthy SR et al. Radiation dose reduction with chest computed tomography using adaptive statistical iterative reconstruction technique: initial experience. Journal of computer assisted tomography 2010; 34: $40-45$

72 Millar AB, Boothroyd AE, Edwards D et al. The role of computed tomography $(\mathrm{CT})$ in the investigation of unexplained haemoptysis. Respir Med 1992; 86: 39-44

73 Bruzzi JF, Remy-Jardin M, Delhaye D et al. Multi-detector row CT of hemoptysis. Radiographics 2006; 26: 3-22

74 Remy-Jardin M, Bouaziz N, Dumont P et al. Bronchial and nonbronchial systemic arteries at multi-detector row CT angiography: comparison with conventional angiography. Radiology 2004; 233: 741 - 749

75 McGuinness G, Beacher JR, Harkin TJ et al. Hemoptysis: prospective high-resolution CT/bronchoscopic correlation. Chest 1994; 105: $1155-1162$

76 Tak S, Ahluwalia G, Sharma SK et al. Haemoptysis in patients with a normal chest radiograph: bronchoscopy-CT correlation. Australas Radiol 1999; 43: 451 - 455

77 Naidich DP, Harkin TJ. Airways and lung: correlation of CT with fiberoptic bronchoscopy. Radiology 1995; 197: 1-12

78 Garzon AA, Gourin A. Surgical management of massive hemoptysis. A ten-year experience. Ann Surg 1978; 187: 267-271

79 Shigemura N, Wan IY, Yu SC et al. Multidisciplinary management of lifethreatening massive hemoptysis: a 10-year experience. Ann Thorac Surg 2009; 87: 849-853

80 Poyanli A, Acunas B, Rozanes I et al. Endovascular therapy in the management of moderate and massive haemoptysis. Br J Radiol 2007; 80: $331-336$

81 Wang GR, Ensor JE, Gupta S et al. Bronchial artery embolization for the management of hemoptysis in oncology patients: utility and prognostic factors. J Vasc Interv Radiol 2009; 20: 722 - 729

82 Fujita T, Tanabe M, Moritani K et al. Immediate and Late Outcomes of Bronchial and Systemic Artery Embolization for Palliative Treatment of Patients With Nonsmall-Cell Lung Cancer Having Hemoptysis. The American journal of hospice \& palliative care 2013; 31: 602-607

83 Park HS, Kim YI, Kim HY et al. Bronchial artery and systemic artery embolization in the management of primary lung cancer patients with hemoptysis. Cardiovasc Intervent Radiol 2007; 30: 638 - 643

84 Schrodt JF, Becker GJ, Scott JA et al. Bronchial artery embolization: monitoring with somatosensory evoked potentials. Work in progress. Radiology 1987; 164: 135-139

85 Vujic I, Pyle R, Hungerford GD et al. Angiography and therapeutic blockade in the control of hemoptysis. The importance of nonbronchial systemic arteries. Radiology 1982; 143: 19-23

86 Ramakantan R, Bandekar VG, Gandhi MS et al. Massive hemoptysis due to pulmonary tuberculosis: control with bronchial artery embolization. Radiology 1996; 200: 691 - 694

87 Fellows KE, Stigol L, Shuster $S$ et al. Selective bronchial arteriography in patients with cystic fibrosis and massive hemoptysis. Radiology 1975; 114: $551-556$

88 Brown AC, Ray CE. Anterior Spinal Cord Infarction following Bronchial Artery Embolization. Seminars in interventional radiology 2012; 29: $241-244$

89 Wong ML, Szkup P, Hopley MJ. Percutaneous embolotherapy for lifethreatening hemoptysis. Chest 2002; 121: 95-102

90 Mesurolle B, Lacombe P, Oanadli $S$ et al. Angiographic identification of spinal cord arteries before bronchial artery embolization. Journal de radiologie 1997; 78: 377 - 380

91 Fellows KE, Khaw KT, Schuster $S$ et al. Bronchial artery embolization in cystic fibrosis; technique and long-term results. J Pediatr 1979; 95: $959-963$ 
92 Remy J, Lemaitre L, Lafitte JJ et al. Massive hemoptysis of pulmonary arterial origin: diagnosis and treatment. Am J Roentgenol Am J Roentgenol 1984; 143: 963 - 969

93 Sbano H, Mitchell AW, Ind PW et al. Peripheral pulmonary artery pseudoaneurysms and massive hemoptysis. Am J Roentgenol Am J Roentgenol 2005; 184: $1253-1259$

94 Picard C, Parrot A, Boussaud V et al. Massive hemoptysis due to Rasmussen aneurysm: detection with helicoidal CT angiography and successful steel coil embolization. Intensive Care Med 2003; 29: $1837-1839$

95 White RI Jr. Bronchial artery embolotherapy for control of acute hemoptysis: analysis of outcome. Chest 1999; 115: 912 -915

96 Hayakawa K, Tanaka F, Torizuka T et al. Bronchial artery embolization for hemoptysis: immediate and long-term results. Cardiovasc Intervent Radiol 1992; 15: 154-158; discussion 158-159

97 Tanaka N, Yamakado K, Murashima S et al. Superselective bronchial artery embolization for hemoptysis with a coaxial microcatheter system. J Vasc Interv Radiol 1997; 8: 65-70

98 Corr PD. Bronchial artery embolization for life-threatening hemoptysis using tris-acryl microspheres: short-term result. Cardiovasc Intervent Radiol 2005; 28: 439-441

99 Hahn S, Kim YJ, Kwon W et al. Comparison of the effectiveness of embolic agents for bronchial artery embolization: gelfoam versus polyvinyl alcohol. Korean journal of radiology: official journal of the Korean Radiological Society 2010; 11: $542-546$

100 Boushy SF, Helgason AH, North LB. Occlusion of the bronchial arteries by glass microspheres. Am Rev Respir Dis 1971; 103: 249-263

101 Ivanick MJ, Thorwarth W, Donohue J et al. Infarction of the left mainstem bronchus: a complication of bronchial artery embolization. Am J Roentgenol Am J Roentgenol 1983; 141: 535-537

102 Naar CA, Soong J, Clore F et al. Control of massive hemoptysis by bronchial artery embolization with absolute alcohol. Am J Roentgenol Am J Roentgenol 1983; 140: 271-272

103 Baltacioglu F, Cimsit NC, Bostanci K et al. Transarterial microcatheter glue embolization of the bronchial artery for life-threatening hemoptysis: technical and clinical results. European journal of radiology 2010; 73: 380-384

104 Razavi MK, Murphy K. Embolization of bronchial arteries with N-butyl cyanoacrylate for management of massive hemoptysis: a technical review. Techniques in vascular and interventional radiology 2007; 10: $276-282$

105 Woo S, Yoon CJ, Chung JW et al. Bronchial artery embolization to control hemoptysis: comparison of $\mathrm{N}$-butyl-2-cyanoacrylate and polyvinyl alcohol particles. Radiology 2013; 269: 594-602

106 Yoo DH, Yoon CJ, Kang SG et al. Bronchial and nonbronchial systemic artery embolization in patients with major hemoptysis: safety and efficacy of N-butyl cyanoacrylate. Am J Roentgenol Am J Roentgenol 2011; 196: W199-204
107 Remy J, Smith M, Lemaitre L et al. Treatment of massive hemoptysis by occlusion of a Rasmussen aneurysm. Am J Roentgenol Am J Roentgenol 1980; 135: 605-606

108 White RI Jr. Pulmonary arteriovenous malformations and hereditary hemorrhagic telangiectasia: embolotherapy using balloons and coils. Arch Intern Med 1996; 156: 2627-2628

109 White RI Jr, Pollak JS, Wirth JA. Pulmonary arteriovenous malformations: diagnosis and transcatheter embolotherapy. J Vasc Interv Radiol 1996; 7: 787-804

110 PollakJS, Saluja S, Thabet A et al. Clinical and anatomic outcomes after embolotherapy of pulmonary arteriovenous malformations. J Vasc Interv Radiol 2006; 17: 35 - 44; quiz 45

111 Andersen PE. Imaging and interventional radiological treatment of hemoptysis. Acta Radiol 2006; 47: 780-792

112 Fruchter $O$, Schneer $S$, Rusanov $V$ et al. Bronchial artery embolization for massive hemoptysis: Long-term follow-up. Asian cardiovascular \& thoracic annals 2014; DOI: 10.1177/0218492314544310

113 Chun JY, Belli AM. Immediate and long-term outcomes of bronchial and non-bronchial systemic artery embolisation for the management of haemoptysis. Eur Radiol 2010; 20: 558 - 565

114 Katoh 0 , Kishikawa T, Yamada $\mathrm{H}$ et al. Recurrent bleeding after arterial embolization in patients with hemoptysis. Chest 1990; 97: 541 546

115 Kim YG, Yoon HK, Ko GY et al. Long-term effect of bronchial artery embolization in Korean patients with haemoptysis. Respirology 2006; 11: $776-781$

116 Osaki S, Nakanishi Y, Wataya $H$ et al. Prognosis of bronchial artery embolization in the management of hemoptysis. Respiration 2000; 67: $412-416$

117 Vidal V, Therasse E, Berthiaume $Y$ et al. Bronchial artery embolization in adults with cystic fibrosis: impact on the clinical course and survival. J Vasc Interv Radiol 2006; 17: 953 -958

118 Tonkin IL, Hanissian AS, Boulden TF et al. Bronchial arteriography and embolotherapy for hemoptysis in patients with cystic fibrosis. Cardiovasc Intervent Radiol 1991; 14: 241 - 246

119 Cohen AM, Doershuk CF, Stern RC. Bronchial artery embolization to control hemoptysis in cystic fibrosis. Radiology 1990; 175: 401 - 405

120 Girard P, Baldeyrou P, Lemoine G et al. Left main-stem bronchial stenosis complicating bronchial artery embolization. Chest 1990; 97: $1246-1248$

121 Lemoigne $F$, Rampal P, Petersen R. Fatal ischemic colitis after bronchial artery embolization. Presse Med 1983; 12: 2056-2057

122 Munk PL, Morris DC, Nelems B. Left main bronchial-esophageal fistula: a complication of bronchial artery embolization. Cardiovasc Intervent Radiol 1990; 13: 95-97

123 Liu SF, Lee TY, Wong SL et al. Transient cortical blindness: a complication of bronchial artery embolization. Respir Med 1998; 92: 983-986 